\title{
Big Five Personality Traits and Academic Performance of Post Graduate Students
}

\author{
${ }^{1}$ Vandana Gandhi, ${ }^{2}$ Prashant Chhajer, ${ }^{3}$ Vishal Mehta \\ ${ }^{1,2,3}$ Assistant Professor, Department of Management Technology, Shri Ramdeobaba College of Engineering and \\ Management, Nagpur, Maharashtra, India. \\ Email: 'gandhivk1@rknec.edu, ${ }^{2}$ chhajerpg@rknec.edu, ${ }^{3}$ mehtav@rknec.edu
}

\section{Received: $20^{\text {th }}$ September 2018, Accepted: $11^{\text {th }}$ October 2018, Published: $31^{\text {st }}$ October 2018}

\begin{abstract}
Personality traits have been significantly affecting human behaviour and there is evidence in literature to prove that performance is correlated to these traits. The traits, if identified early can be helpful in understanding the performance / non- performance of human beings, thus, creating an opportunity to improve upon these traits with an objective to improve performance. The present study is focused on understanding the traits exhibited by the Post Graduate students and linking their academic performance with these traits. The objective is to understand which personality traits lead to better performance as compared to others. The study would be helpful in understanding how the performance of students can be improved by working upon the personality of the students. Students differ in learning and they feel comfortable and perform best in an environment which suits their personality. Students' academic performance is one of the crucial elements that provides them the opportunity to excel in their career. Big Five personality model (OCEAN) is used to understand the personality traits of students. Regression analysis has been done to understand the effect of each parameter on the performance level.
\end{abstract}

\section{Keywords}

Personality, Traits, OCEAN, Performance

\section{Introduction}

Traditionally, across the globe, academic performance has been associated with intelligence rather than anything else. It was only in 1900s' that research was carried out to check the possibility of personality traits affecting the academic performance. Lot of researchers studied this hitherto rarely covered aspect. Cattell \& Butcher, 1968; Eysenck, 1967; Kline \& Gale, 1977 ; explored this relationship, while Mehta \& Kumar, 1985, were of the opinion that personality factors do not have any significant influence on the academic performance. Certain other experts have opined that academic performance depends both on motivation and intelligence,( Busato, Prins, Elshout, \& Hamaker, 1999). They felt that the process of learning is closely related to both the factors. Intelligence, answer a basic question 'what a person can do' while personality gives an idea as to 'how the person will do it'. It is the perfect combination of 'what' and 'how' that differentiates an academically successful candidate from a not so successful or an unsuccessful one. The purpose of this study is to explore the possibility of personality traits affecting the results of the students pursuing Post Graduation in the field of Management.

\section{Literature Review}

Blickle, 1996, in a study found that personality traits are good enough to influence and bring about certain variations in the academic performance. While there are others like Klein (1996), who felt that a lot more research is required to identify the role of each trait in improving the motivation. Gellatly (1996), said that inconsistent results have been produced by studies linking personality traits with variables. Austin \& Klein, 1996, concluded that there was a need to study the impact of a systems of traits rather than an individual trait. The five factor model is perhaps the most comprehensive system of traits that can be used to study the impact of personality traits on the performance of human beings. The other researchers have also contributed in further developing the model and identifying the qualities exhibited by individuals scoring high on each of these factors.

John \& Srivastava, 1999, created an inventory of Big Five Factors and then divided each of these factors into personality facets and gave a correlating trait. They found that Openness to experience indicates a person who by nature is curious, imaginative, artistic and someone with wide areas of interest. A person who scores high on Conscientiousness tends to be careful, organized, efficient, thorough and not impulsive. Watson \& Clark, 1997, found that a person high on Extraversion shows a tendency to be sociable, dominant and positive. Barrick \& Mount, 1991, people tend to be kind, gentle, trusting and trustworthy and warm when they are high on Agreeableness. Neuroticism, denotes emotional stability or the lack of it. A high score shows the person is unable to cope with the stress and is prone to be anxious and is likely to be depressed. 
Numerous studies have been done to explore the relationship between the big five personality factors and performance. Gellatly (1996), found that goal motivation for goal setting was linked to Conscientiousness while Malouff, Schutte, Bauer, \& Mantelli, 1990 , found that the people high on neuroticism are less likely to be goal oriented Barrick et al (1993), in a study found that the extraversion was correlated with goal level but not with goal commitment.

Timothy A. Judge and Remus Ilies ,2002, found very little literature on the remaining two factors and concluded that very little has been done.

McCrae \& Costa, 1994; Roberts \& Del Vecchio, 2000, said that the behaviours can be changed, this is an important finding because based on the results of the students it can be decided what changes need to be brought in the student. Maureen A. Conard,2005, found that Conscientiousness is one trait which if improved can bring about changes in the performance. The literature suggests that once identified there exists a scope for improving the performance of the students by bringing about certain behavioural changes.

\section{Objectives of the Study:}

To assess the personality traits of students of Masters of Business Administration.

To assess the relationship between the personality traits of the students and their academic performance.

\section{Hypothesis of Study:}

H1: Students' academic performance is affected by their personality traits.

\section{Research Methodology}

OCEAN model, also known as big five personality traits, is used to study the personality traits of students. ANOVA is used to study the relationship between Gender, OCEAN personality traits and the academic performance of the students. The sample consists of 120 students of Masters of Business Administration who have given exams of $1^{\text {st }}$ year and have their results. SPSS is used for analysis.

\section{Data Finding and Analysis}

The objective of the study is to assess the relationship between the academic performance of the sample students and the big five personality traits using the OCEAN model.

One way ANOVA was used to assess the relationship between OCEAN and students' academic performance. CGPA was used to represent Students' academic performance.

Following chart shows the number of students who ticked Relatively Low (1), About Average (2) and Relatively High (3) for each of the personality traits:

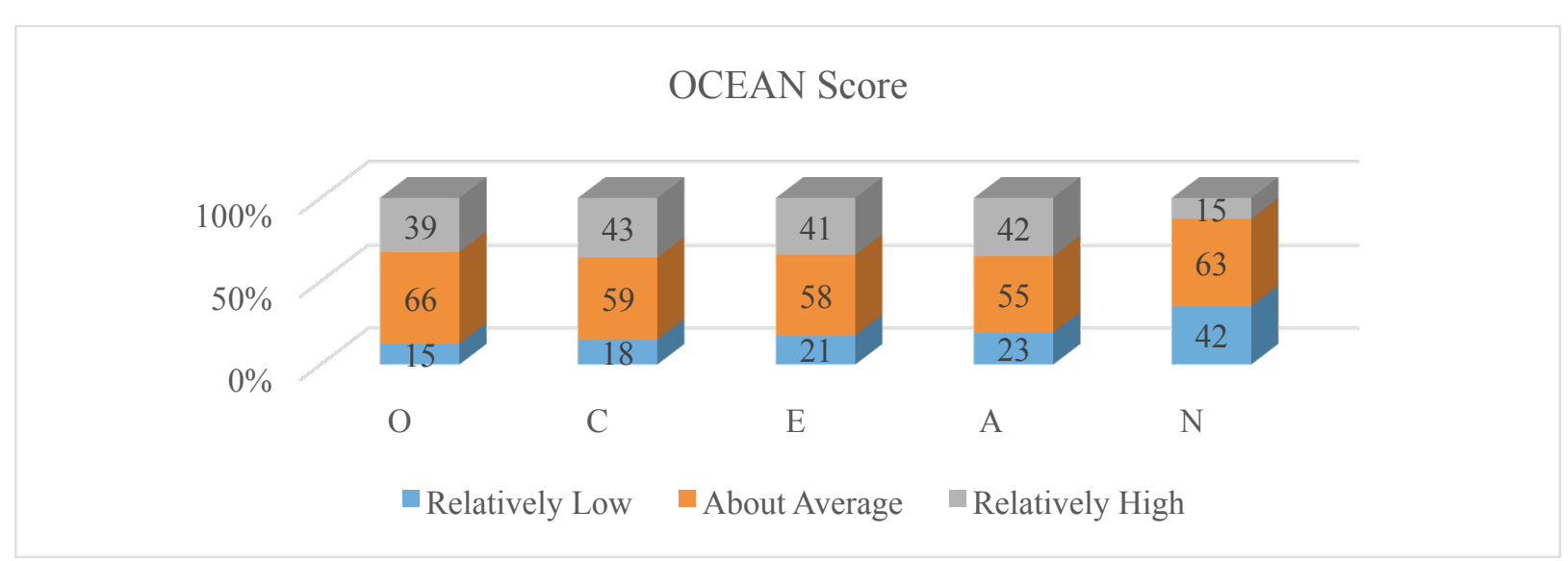

\section{Chart 1: OCEAN Score}

Most of the students have scored about average and relatively high in case of the personality traits Openness, Conscientiousness, Extraversion and Agreeableness whereas in case of neuroticism most of the students have scored relatively low and about average. To begin with Gender is used as the independent factor. One way ANOVA is used to study the relationship between Gender and CGPA. The number of female students was 72 and that of male students was 48. 


\begin{tabular}{|c|c|c|c|c|c|}
\hline \multicolumn{6}{|l|}{ ANOVA } \\
\hline \multicolumn{6}{|l|}{ CGPA } \\
\hline & Sum of Squares & df & Mean Square & $\mathrm{F}$ & Sig. \\
\hline Between Groups & 16.922 & 1 & 16.922 & 6.149 & .015 \\
\hline Within Groups & 324.758 & 118 & 2.752 & & \\
\hline Total & 341.679 & 119 & & & \\
\hline
\end{tabular}

Table 1: ONEWAY CGPA BY Gender

Table 1 shows the relationship between CGPA and Gender. The p-value (0.015) is less than 5\%, the assumed level of significance, which shows that the academic performance of students is dependent upon gender.

\begin{tabular}{|l|l|l|l|l|l|}
\hline ANOVA & \multicolumn{2}{|l|}{} \\
\hline CGPA & Sum of Squares & df & Mean Square & F & Sig. \\
\hline & 23.105 & 2 & 11.553 & 4.243 & .017 \\
\hline Between Groups & 318.574 & 117 & 2.723 & & \\
\hline Within Groups & 341.679 & 119 & & & \\
\hline Total &
\end{tabular}

\section{Table 2: ONEWAY CGPA BY Openness}

Relatively high in openness represents imaginative, curious whereas relatively low value shows conventional. With p-value (0.017) less than $5 \%$ (table 2), openness as a personality trait does affect the academic performance of students.

\begin{tabular}{|c|c|c|c|c|c|}
\hline \multicolumn{6}{|l|}{ ANOVA } \\
\hline \multicolumn{6}{|l|}{ CGPA } \\
\hline & Sum of Squares & $\mathrm{df}$ & Mean Square & $\mathrm{F}$ & Sig. \\
\hline Between Groups & 22.015 & 2 & 11.008 & 4.029 & .020 \\
\hline Within Groups & 319.664 & 117 & 2.732 & & \\
\hline Total & 341.679 & 119 & & & \\
\hline
\end{tabular}

Table 3: ONEWAY CGPA BY Conscientiousness

Relatively high in conscientiousness represents punctual, organized whereas relatively low value represents disorganized. The p-value (0.020), being less than $5 \%$, implies that conscientiousness affects the academic performance of the students.

\begin{tabular}{|l|l|l|l|l|l|}
\hline ANOVA & & & & & \\
\hline CGPA & Sum of Squares & df & Mean Square & F & Sig. \\
\hline Between Groups & 4.688 & 2 & 2.344 & .814 & .446 \\
\hline Within Groups & 336.991 & 117 & 2.880 & & \\
\hline Total & 341.679 & 119 & & & \\
\hline
\end{tabular}

\section{Table 4: ONEWAY CGPA BY Extraversion}

Relatively high in extraversion characterizes active, expressive whereas relatively low value shows quiet, reserved. The p-value (0.446) shows that extraversion does not affect the academic performance. 


\begin{tabular}{|l|l|l|l|l|l|}
\hline ANOVA & & & & & \\
\hline CGPA & Sum of Squares & df & Mean Square & F & Sig. \\
\hline & 6.089 & 2 & 3.044 & 1.061 & .349 \\
\hline Between Groups & 335.591 & 117 & 2.868 & & \\
\hline Within Groups & 341.679 & 119 & & & \\
\hline Total & & & & \\
\hline
\end{tabular}

Table 5: ONEWAY CGPA BY Agreeableness

Relatively high in agreeableness characterizes trustworthy, good natured whereas relatively low value shows critical, suspicious. The p-value is (0.349) which implies that agreeableness also does not affect the academic performance.

\begin{tabular}{|l|l|l|l|l|l|}
\hline ANOVA & & & & & \\
\hline CGPA & Sum of Squares & df & Mean Square & F & Sig. \\
\hline & 38.117 & 2 & 19.058 & 7.346 & .001 \\
\hline Between Groups & 303.563 & 117 & 2.595 & & \\
\hline Within Groups & 341.679 & 119 & & & \\
\hline Total & & & & \\
\hline
\end{tabular}

Table 6: ONEWAY CGPA BY Neuroticism

Relatively high in neuroticism characterizes temperamental, agitated whereas relatively low value shows calm, stable. The p-value (0.001), being less than 5\%, implies that neuroticism affects the academic performance.

\section{Conclusion}

The results show that the personality traits Openness, Conscientiousness and Neuroticism significantly affect the academic performance of the students, whereas the other two personality traits Extraversion and Agreeableness do not significantly affect the academic performance.

The students have scored relative high and about average in openness as well as conscientiousness. High in openness represents imaginative, curious and high in conscientiousness represents punctual and organized. The results show that being high in both leads to better academic performance. The students have scored relatively low and about average in neuroticism. Low neuroticism shows calmness and stability. The results indicate that being low in this trait also leads to better academic performance. High in extraversion and agreeableness represent active, expressive, trustworthy, and good natured. The results could not significantly establish relationship between these traits and academic performance. Gender also affects the academic performance of the students.

Based on the study it can be said that students should analyze their personality traits and work towards being relatively high in Openness, Conscientiousness, Extraversion, Agreeableness and being relatively low in neuroticism.

\section{References}

1. Blickle, G. (1996). Personality traits, learning strategies, and performance. European Journal of Personality, 10, 337-352.

2. Cattell, R., \& Butcher, H. (1968). The prediction of achievement and creativity. Indianapolis: Bobbs-Merrill.

3. Cattell, R., \& Kline, P. (1977). The scientific analysis of personality and motivation. New York: Academic Press.

4. Kline, P., \& Gale, A. (1971). Extraversion, neuroticism and performance in a psychology examination. British Journal of Educational Psychology, 41, 90-94.

5. Mehta, P., \& Kumar, D. (1985). Relationships of academic achievement with intelligence, personality, adjustment, study habits and academic motivation. Journal of Personality and Clinical Studies, 1, 57- 68.

6. Busato, V. V., Prins, F. J., Elshout, J. J., \& Hamaker, C. (2000). Intellectual ability, learning style, achievement motivation and academic success of psychology students in higher education. Personality and Individual Differences, 29, 1057-1068.

7. Austin, J. T., \& Klein, H. J. (1996). Work motivation and goal striving. In K. R. Murphy (Ed.), Individual differences and behaviour in organizations (pp. 209-257). San Francisco: Jossey-Bass. 
8. Gellatly, I. R. (1996). Conscientiousness and task performance: Test of cognitive of Applied Psychology, 81,474-482.

9. John, O. P., \& Srivastava, S. (1999). The Big Five trait taxonomy: History, measurement, and theoretical perspectives. In L. A. Pervin \& O. P. John (Eds.), Handbook of personality: Theory and research (2nd ed., pp. 102-138). New York: Guilford Press.

10. Watson, D., \& Clark, L. A. (1997). Extraversion and its positive emotional core. In R. Hogan, J. A. Johnson, \& S. R. Briggs (Eds.), Handbook of personality psychology (pp. 767-793). San Diego, CA: Academic Press.

11. Barrick, M. R., \& Mount, M. K. (1991). The Big Five personality dimensions and job performance: A metaanalysis. Personnel Psychology, 44, 1-26.

12. Malouff, J., Schutte, N., Bauer, M., Mantelli, D. (1990). Development and evaluation of a measure of the tendency to be goal oriented. Personality and Individual Differences, 11, 1191-1200.

13. Barrick, M. R., Mount, M. K., \& Strauss, J. P. (1993). Conscientiousness and performance of sales representatives: Test of the mediating effects of goal setting. Journal of Applied Psychology, 78, 715-722.

14. Medical students' personality characteristics and academic performance: a five-factor model perspective ,Filip Lievens,1 Pol Coetsier,1 Filip De Fruyt2 \& Jan De Maeseneer ; Blackwell Science Ltd MEDICAL EDUCATION 2002;36:1050-1056

15. Personality predicts academic performance: Evidence from two longitudinal university samples; T. ChamorroPremuzic, A. Furnham / Journal of Research in Personality 37 (2003) 319-338.

16. Aptitude is Not Enough: How Personality and Behavior Predict Academic Performance ; Maureen A. Conard ; Brief report / Journal of Research in Personality xxx (2005) xxx-xxx

17. Relationship of Personality to Performance Motivation: A Meta-Analytic Review; Timothy A. Judge and Remus Ilies; Journal of Applied Psychology Copyright 2002 by the American Psychological Association, Inc. 2002, Vol. 87, No. 4, 797-807.

18. Costa, P. T., Jr., \& McCrae, R. R. (1992). Revised NEO Personality Inventory (NEO-PI-R) and NEO FiveFactor Inventory (NEO-FFI) professional manual. Odessa, FL: PAR.

19. Roberts, B. W., \& DelVecchio, W. F. (2000). The rank-order consistency of personality traits from childhood to old age: A quantitative review of longitudinal studies. Psychological Bulletin, 126, 3-25. 